\title{
Penggunaan Dandan, Dondon, Gungun, dan Masumasu pada Artikel Asahi Shinbun (edisi Juni 2020)
}

\author{
Ni Putu Desi Ratnasari ${ }^{1 *}$, Renny Anggraeny ${ }^{2}$, Ngurah Indra Pradhana ${ }^{3}$ \\ ${ }^{[1,2,3]}$ Program Studi Sastra Jepang, Fakultas Ilmu Budaya, Universitas Udayana \\ Denpasar, Bali-Indonesia \\ 1'[desiratna1522@gmail.com], ${ }^{2}$ [renny_anggraeny@unud.ac.id], ${ }^{3}$ [indra_pradana@unud.ac.id]
}

\begin{abstract}
Abstrak
Penelitian ini berjudul "Penggunaan Dandan, Dondon, Gungun, dan Masumasu pada artikel Asahi Shinbun (edisi Juni 2020)". Dandan, dondon, gungun, dan masumasu memiliki persamaan yaitu berarti "semakin", namun ada perbedaan dari keempat fukushi tersebut yang terlihat pada kalimat yang tercantum dalam artikel Asahi Shinbun. Penelitian ini bertujuan untuk mengetahui struktur, fungsi, dan makna kontekstual pada fukushi dandan, dondon, gungun, dan masumasu yang ditemukan pada artikel Asahi Shinbun edisi Juni 2020. Metode yang digunakan dalam penelitian ini adalah metode deskriptif kkualitatif. Data yang telah terkumpul dianalisis dengan menggunakan teori sintaksis Verhaar dan teori makna kontekstual Pateda yang didukung dengan konsep fukushi dandan, dondon, gungun, dan masumasu oleh Akira. Hasil penelitian ini menunjukkan struktur yang membentuk kalimat berisi dandan, dondon, gungun, dan masumasu yaitu diikuti oleh kata kerja, kata benda, kata sifat, dan ada pula yang diikuti oleh frasa kerja. Dandan menunjukkan bahwa berfungsi untuk menerangkan kata kerja, kata benda, dan frasa kerja. Dondon berfungsi menerangkan kata kerja dan kata benda. Gungun berfungsi menerangkan kata kerja saja. Masumasu berfungsi menerangkan kata kerja dan kata sifat. Makna kontekstual yang memengaruhi dandan terdapat empat jenis, yaitu konteks waktu, konteks suasana hati pembicara/pendengar, konteks situasi, dan konteks tujuan. Makna kontekstual yang memengaruhi dondon terdapat tiga jenis, yaitu konteks objek, konteks tujuan, dan konteks situasi. Makna kontekstual yang memengaruhi gungun terdapat dua jenis, yaitu konteks suasana hati pembicara/pendengar dan konteks tujuan serta makna kontekstual yang memengaruhi masumasu terdapat empat jenis, yaitu konteks waktu, konteks objek, konteks situasi, dan konteks suasana hati pembicara/pendengar.
\end{abstract}

Kata kunci: fukushi; dandan; dondon; gungun; masumasu

\begin{abstract}
This research is entitled "The use of Dandan, Dondon, Gungun, and masumasu in the Asahi Shinbun article (June 2020 edition)". Dandan, dondon, gungun, and masumasu have something in common, which means "more and more", but there are differences between the four adverb that can be seen in the sentences listed in the Asahi Shinbun article. This study aims to determine the structure, function, and contextual meaning of adverb dandan, dondon, gungun, and masumasu found in the June 2020 edition of the Asahi Shinbun article. The collected data were analyzed using Verhaar's syntactic theory which is supported by the concepts of fukushi dandan, dondon, gungun, and masumasu by Akira and Pateda's theory of contextual meaning. The method used to analyze the data is the descriptive kualitative method. Based on the results of the analysis, the structure that forms a sentence contains dandan, dondon, gungun, and masumasu, namely followed by verbs, nouns, adjectives, and some are followed by verbs. Dandan shows that it serves to explain verbs, nouns, and verbs. Dondon serves to explain verbs and nouns. Gungun functions only to explain verbs. Masumasu functions to explain verbs and adjectives. Four types of contextual meanings affect dandan sentences, namely the context of the time, the context of the mood of the speaker/listener, the context of the situation, and the context of the goal. Three types of contextual meanings influence the dondon sentence, namely the object context, the objective, and the situation context. Two types of contextual meanings affect the sentence, namely the mood context of the speaker/listener, and the context of the goal and
\end{abstract}


then the contextual meaning affects the masumasu sentence are four types, namely the context of the time, the context of the object, the context of the situation, and the context of the mood of the speaker/listener.

Key words : adverb; dandan; dondon; gungun; masumasu

\section{Pendahuluan}

Komunikasi adalah salah satu aspek yang paling penting dalam kehidupan sehari-hari dan cara untuk berhubungan dengan masyarakat. Kita sebagai masyarakat dapat saling mengerti maksud dari pembicaraan seseorang secara baik dengan berkomunikasi. Kata keterangan adalah salah satu bagian yang biasanya digunakan untuk melengkapi kalimat. Kata keterangan dalam bahasa Jepang disebut dengan fukushi. Fukushi merupakan kata keterangan yang digunakan untuk menjelaskan kata kerja, kata sifat, maupun kata kerja bantu. Matsuoka (dalam Sudjianto, 2014:165) menyatakan bahwa fukushi adalah salah satu bagian dari kelas kata yang tidak mengalami perubahan bentuk.

Bahasa Jepang jika dilihat berdasarkan penggunaannya secara lisan, tulisan, formal atau pun non-formal terdapat beberapa fukushi yang memiliki kesamaan pengertian, contohnya dandan, dondon, gungun, dan masumasu. Keempat fukushi tersebut secara harfiah memiliki arti 'semakin' dalam bahasa Indonesia, namun memiliki perbedaan proses perubahan kejadian satu ke hal lainnya. Oleh karena itu, penulis melakukan penelitian tentang fukushi dandan, dondon, masumasu dan gungun yang membahas dari segi struktur pembentukan, fungsi yang terkandung dan makna yang ada pada keempat fukushi tersebut agar masyarakat atau pemelajar bahasa Jepang menjadi lebih paham dengan begitu tidak mengalami kebingungan dalam penggunaannya. Penelitian ini menggunakan artikel pada asahi shinbun edisi bulan Juni 2020 sebagai sumber data yang menganalisis struktur dan makna dari fukushi dandan, dondon, masumasu dan gungun yang memiliki arti yang sama, yaitu 'semakin'.

Berdasarkan latar belakang yang telah diuraikan, maka dapat dirumuskan permasalahan sebagai berikut:

1) Bagaimanakah struktur dan fungsi dandan, dondon, gungun, dan masumasu pada artikel Asahi Shinbun (edisi Juni 2020)?

2) Bagaimanakah makna kontekstual dandan, dondon, gungun, dan masumasu pada artikel Asahi Shinbun (edisi Juni 2020)? 
Penelitian ini bertujuan untuk menambah wawasan pembaca dan referensi penelitian di bidang linguistik bahasa Jepang. Secara khusus juga bertujuan untuk mengetahui struktur, fungsi dan makna fukushi dandan, dondon, gungun, dan masumasu pada artikel Asahi Shinbun (edisi Juni 2020).

\section{Metode dan Teori}

\subsection{Metode Penelitian}

Metode pengumpulan data yang digunakan pada penelitian ini adalah metode simak dan teknik catat. Metode analisis data yang digunakan, yaitu metode deskriptif kemudian dijabarkan dengan metode informal. Sumber data yang digunakan dalam penelitian ini berupa artikel pada Asahi Shinbun. Alasan yang membuat penulis menggunakan artikel ini karena Asahi Shinbun merupakan koran terkenal kedua di Jepang dengan bahasa yang digunakan sudah diterima oleh masyarakat Jepang dalam kehidupan sehari-hari dan juga sebagai pencetus bidang media informasi khususnya koran di Jepang pada tahun 1879. Asahi Shinbun juga menjadi koran dengan penjualan terbanyak kedua di dunia pada tahun 2018, sehingga banyak yang makin mengenal koran ini dan juga artikel-artikel yang dipublikasikan juga dapat dipertanggungjawabkan karena tertera nama editor dan jurnalis yang membuat artikel tersebut.

\subsection{Teori}

Teori yang digunakan, yaitu teori sintaksis oleh Verhaar (2010) dengan mengacu pada konsep yang dikemukakan Akira (1998) untuk mengetahui struktur dan fungsi dari keempat fukushi tersebut, yaitu dandan, dondon, gungun, dan masumasu. Teori kedua, yaitu teori makna kontekstual Pateda (2010) untuk menganalisis makna kontekstualnya.

\section{Hasil dan Pembahasan}

Bagian ini menguraikan hasil analisis meliputi struktur dan fungsi serta makna kontekstual dari fukushi dandan, dondon, gungun, dan masumasu yang memiliki pengertian yang sama, yaitu 'semakin'. Berikut merupakan uraian mengenai keempat fukushi tersebut yang terdapat dalam artikel Asahi Shinbun (edisi Juni 2020). 


\subsection{Dandan}

Dandan merupakan kata keterangan yang mengalami perubahan secara perlahan-lahan. Fukushi dandan memiliki rentang waktu yang lebih lama terhadap perubahan keadaan satu kondisi ke situasi selanjutnya menurut Akira (1998:2298). Dandan memiliki tiga kategori fungsi yang ditemukan, yaitu menerangkan kata kerja, kata benda dan frasa kerja.

”順を追ってゆっくりと変化してゆくさま。しだいしだいに。次から次 へと続くさま。かずかず。あれやこれや。”

'jun wo otte yukkuri to henkashite yuku sama. Shidai shidai ni. Tsugi kara tsugi he to tsudukusama. Kazukazu. Are ya kore ya.'

'Hal yang berubah secara perlahan. Bertahap. Hal yang berlanjut satu demi satu. Kazukazu. Are ya kore ya.'

Berdasarkan pengertian tersebut maka perubahan yang dialami pada dandan membutuhkan waktu yang cenderung lebih lama dibanding dondon. Proses perubahan yang dialami oleh dandan secara perlahan-lahan atau satu persatu sehingga biasanya melebihi satu kondisi atau masa yang artinya tidak bisa terselesaikan dalam waktu yang relatif sebentar.

\subsubsection{Menerangkan kata kerja}

Berikut merupakan fungsi dandan yang digunakan untuk menjelaskan kata kerja.

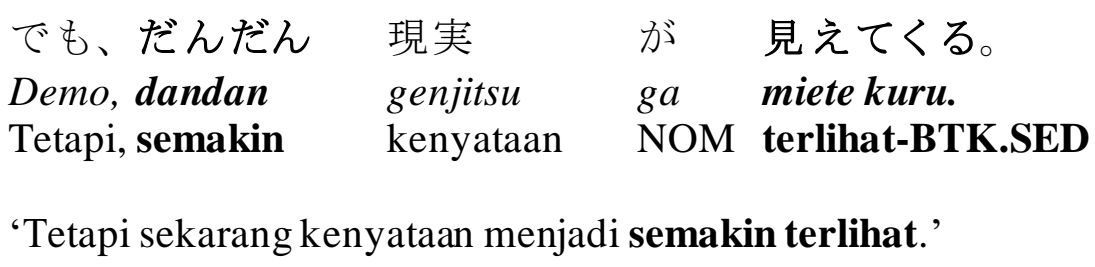

'Tetapi sekarang kenyataan menjadi semakin terlihat.'

Data (1) terdapat fukushi dandan yang digunakan untuk menerangkan kata kerja intransitif, yaitu miete kuru. Miete kuru berasal dari kata kerja bentuk potensial berupa mieru yang secara harfiah berarti 'terlihat'. Kata tersebut diikuti oleh pola -te kuru yang berarti suatu hal yang menyatakan penampakan yang semakin terlihat, sehingga menjadi miete kuru. Pada kalimat tersebut, dandan miete kuru jika diubah ke dalam bahasa Indonesia menjadi 'semakin (menjadi) terlihat'. Makna dari kata 'semakin terlihat' disana menjelaskan mengenai penyebab suatu kondisi yang dialami oleh pembicara menjadi semakin jelas. 


\subsubsection{Menjelaskan suatu kondisi dengan konteks}

Kalimat pada data (1) menerangkan keadaan saat mewawancarai salah satu pemain catur Jepang (Igo) memang memiliki impian menjadi pemain internasional. Pada kondisi sebelumnya, dijelaskan bahwa sejak awal ia mengatakan bahwa akan mengejar impiannya agar bisa menjadi pemain Igo internasional meskipun mengesampingkan pendidikannya. Sampai pada akhimya ia telah mencapai impian tersebut, namun ternyata semakin lama ia berpikir bahwa kenyataan hidup tidak lah mudah, membutuhkan tingkat pendidikan yang baik untuk bisa mendapat pekerjaan dan bertahan hidup. Pendidikan yang selama ini telah banyak tertinggal akhirnya bisa dilanjutkan dengan masuk kuliah dan dijalani dengan baik untuk mendapat gelar sarjana. Data nomor (1) memiliki makna kontekstual yang terkandung adalah konteks situasi, karena mengalami situasi yang menyebabkan perubahan pada kehidupan selanjutnya si pembicara. Dandan miete kuru jika diterjemahkan ke dalam bahasa Indonesia menjadi 'semakin terlihat', kenyataan hidup sekarang memang tidak mudah yang menyebabkan perubahan dalam pandangan pembicara. Secara perlahan mengubah pandangan pembicara, berawal dari cita-cita menjadi pemain igo internasional sampai akhimya memilih untuk melanjutkan pendidikan ke jenjang sarjana.

\subsubsection{Menerangkan kata benda}

Berikut merupakan fungsi dandan yang digunakan untuk menjelaskan kata benda.

\begin{tabular}{|c|c|c|c|c|c|c|c|}
\hline 記事 & & に「あとは & 戌判 & & の & 補 & な \\
\hline$K i j i-c$ & $\bar{u} u$ & ni [ato wa & kakus & aibankar & n no & hosok & tekina \\
\hline Dala & artikel & LOKsetiap hak & xim & & GEN & & p1 \\
\hline 意見 & の & 執筆 & 並行 & Jして. & 最後 & の & 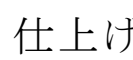 \\
\hline ken & no & shippitsu to & heik & oushite, & saigo & no & shiage \\
\hline Penda & patGEN & penulisan PAI & R sej & & terakhi & r GEN & hasil \\
\hline の & ため & 合議 & を & 二、三 & 三回開き & & 終わり \\
\hline no & tame & gougi & wo & $2,3 \mathrm{ka}$ & ilbiraki, & & wari \\
\hline GEN & untuk & GEN diskusi & $\mathrm{AKU}$ & $2,3 \mathrm{ka}$ & li buka & & esai \\
\hline 次第 & |決期 | & 指定 & の & 運びに & こなるも & の & と \\
\hline shid & hanke & tei & no & hakobi & ininar & mono & \\
\hline pen & in & & G & & gat & & \\
\hline
\end{tabular}




\section{みられる」「斎藤（悠輔）、下飯坂（潤夫）、 mirareru] [Saitou (Yuusuke), Shimoizaka (Jun otto), terlihat Saitou Yuusuke, Shimoiizaka (Jun Otto) \\ BTK.POT}

$\begin{array}{llll}\text { 入江 (敏郎) } & \text { 判事ら } & \text { が } & \text { 執筆、 } \\ \text { Irie (Toshirou) } & \text { hanji-ra } & g a & \text { shippitsu, } \\ \text { Irie (Toshirou) } & \text { para juri } & \text { NOM ditulis }\end{array}$

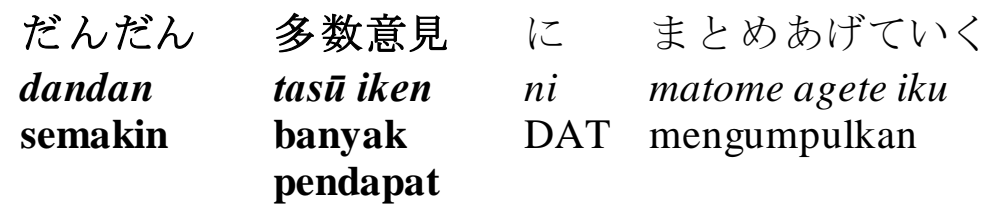

$\begin{array}{llllll}\text { やり方 } & \text { 取ったようだ」 } & \text { として、 } & \text { だれ } & \text { が } \\ \text { Yarikata } & \text { wo totta youda] } & \text { to shite, } & \text { dare } & \text { ga } \\ \text { Cara } & \text { AKU mengambil } & \text { sebagai } & \text { siapa } & \text { NOM } \\ & & \text { BTK.LAM } & & & \end{array}$

$\begin{array}{lllll}\text { 判決文 } & \text { を } & \text { 起案していた かも } & \text { 書かれていた } \\ \text { Hanketsubun } & \text { wo } & \text { kian shite ita } & \text { kamo } & \text { kaka rete ita } \\ \text { Hukuman } & \text { AKU } & \text { merencanakan } & \text { mungkin } & \text { menulis }\end{array}$

$\begin{array}{cllll}\text { (裁判官たち } & \text { が } & \text { 記者 } & \text { の } & \text { 材におおらか } \\ \text { (saibankan-tachi } & \text { ga } & \text { kisha } & \text { no } & \text { shuzainiōraka } \\ \text { Para juri } & \text { NOM } & \text { wartawan } & \text { GEN } & \text { takut wawancara }\end{array}$

に応じていた 時代だったの だろう）。

ni ōjite ita jidaidatta no darou).

DAT menanggapi jaman GEN KOP

'Dalam artikel itu, "selain menulis opini tambahan dari masing-masing hakim, diharapkan pertemuan terakhir akan diadakan beberapa kali, dan tanggal putusan akan ditentukan segera setelah selesai." Saito (Yusuke), Shimoiizaka (Juno), Juri (Toshiro), dll menulis dan tampaknya telah mengadopsi metode konsolidasi secara bertahap menjadi semakin banyak pendapat.'

Data (2) menunjukkan bahwa dandan berfungsi untuk menerangkan kata benda. Tasuu iken berasal dari dua kata benda, yaitu tasuu yang artinya 'berjumlah banyak' dan iken yang secara harfiah berarti 'pendapat'. Dandan tasuu iken jika diterjemahkan ke dalam bahasa Indonesia menjadi 'semakin banyak pendapat', yang menunjukkan bahwa pendapat yang dikumpulkan dari berbagai pihak akan menjadi banyak setelah mengadopsi metode dalam pengambilan keputusan. 


\subsubsection{Menerangkan suatu situasi dengan konteks tujuan}

Makna kontekstual yang terkandung pada data (2) adalah konteks tujuan. Situasi sebelumnya menjelaskan tentang keadaan sulitnya mengambil keputusan dalam suatu proses pengadilan. Sejumlah pendapat yang diperlukan agar bisa mencapai simpulan dan keputusan yang dapat diambil dengan adil. Adanya pengharapan terhadap opini yang dikeluarkan oleh masing-masing hakim, sehingga dalam waktu dekat bisa menentukan tanggal untuk membuat keputusan. Dandan tasuu iken jika dilihat pada data berarti 'semakin banyak pendapat', sesuai dengan konsep pada Akira yang menyatakan bahwa dandan memiliki proses perubahan yang relatif lebih lambat, secara bertahap untuk dapat menempuh tujuan yang diinginkan, yaitu mendapatkan keputusan setelah mengumpulkan pendapat.

\subsection{Dondon}

Dondon merupakan kata keterangan yang memiliki beberapa persamaan dengan dandan seperti yang sudah dipaparkan pada pengertian dandan. Akira (Daijisen, 1998:2657) menerangkan bahwa:

“物を続けざまに強く打ったり大きく鳴らしたりする音を表す語。物事 が勢いよく進行するさま。また、物事をためらわないでするさま。”

"mono wo tsudzukezama ni tsuyoku uttari ookiku narashitarisuru oto wo arawasu go. Monogoto ga ikioi yoku shinkou suru sama. Mata, monogoto wo tamerawanaide suru sama."

'Kata yang mendeskripsikan suara memukul atau membuat suara keras berturutturut. Segalanya berjalan dengan cepat. Juga, melakukan sesuatu dengan tanpa keraguan.'

Pengertian dari kalimat kedua tersebut adalah perubahan sesuatu yang terjadi secara natural dan tanpa adanya keraguan. Dengan demikian, sesuai dengan penelitian penulis, maka pengertian kedua yang tepat digunakan sebagai pengertian dondon yang berarti 'semakin'. Terdapat dua fungsi dondon yang ditemukan, yaitu untuk menerangkan kata kerja dan kata benda.

\subsubsection{Menerangkan Kata Benda}

Berikut merupakan fungsi dandan yang digunakan untuk menjelaskan kata benda. 


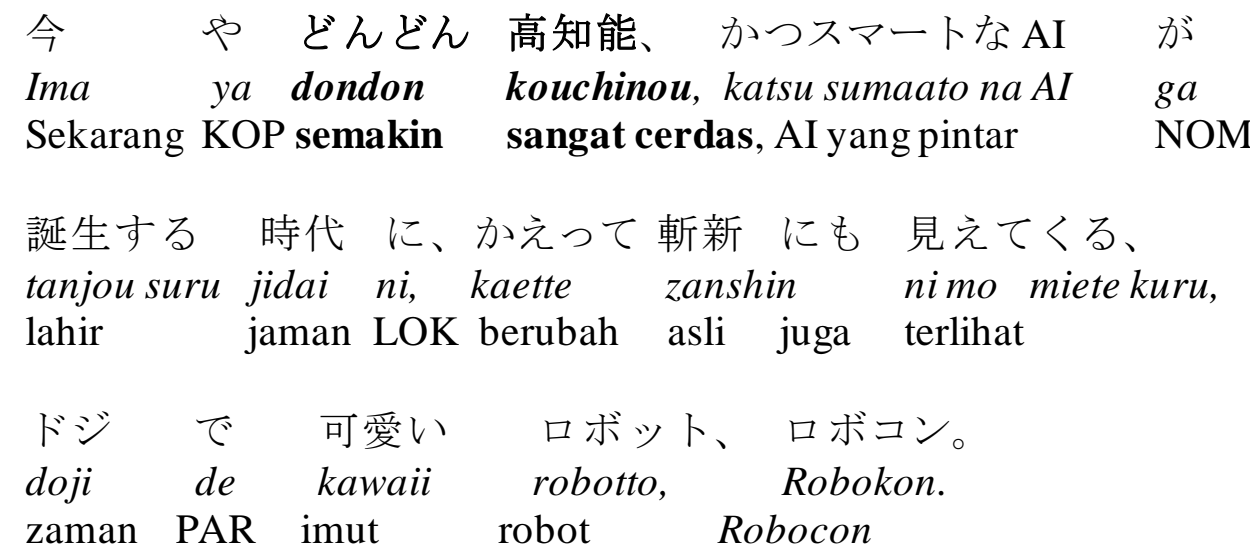

'Robocon, robot yang sangat imut, menjadi semakin inovatif di zaman AI yang semakin sangat cerdas dan pintar.'

Mengacu pada konsep Akira mengenai struktur dan fungsi dari dondon, biasanya hanya diikuti oleh kata kerja, namun pada kalimat pada data (3) terlihat bahwa dondon berfungsi untuk menerangkan kata benda, yaitu kouchinou. Kouchinou secara harfiah berarti 'cerdas tingkat tinggi/sangat cerdas'. Kalimat tersebut, dondon kouchinou jika diterjemahkan ke dalam bahasa Indonesia, yaitu adalah 'semakin cerdas'. Jadi, pada kalimat tersebut dondon berfungsi untuk menerangkan kata benda kouchinou untuk menjelaskan keadaan bahwa tingkat kecerdasan yang semakin bertambah pada robocon di zaman sekarang sangat inovatif.

\subsubsection{Menjelaskan suatu kondisi dengan konteks objek}

Makna kontekstual yang terlihat pada data (3) berupa konteks objek, karena menjelaskan sesuatu yang menjadi objek pembicaraan. Kalimat sebelumnya menjelaskan bahwa terdapat banyak film yang semakin menarik perhatian masyarakat. Salah satu film baru yang akan tayang pada musim panas tahun ini berjudul 'Ganbareiiwa!! Robocon'. Film tersebut menceritakan tentang peningkatan teknologi jaman sekarang. Segala sesuatu yang dapat membantu kehidupan manusia dibuat dengan baik, contohnya seperti robot pintar atau yang disebut dengan robocon. Konteks objek yang dimaksud pada data (3) adalah menjelaskan kemampuan robot yang semakin cerdas dan pintar serta inovatif. Dondon kouchinou jika diterjemahkan ke dalam bahasa Indonesia menjadi 'semakin cerdas', yang artinya bahwa secara cepat mengalami perubahan terhadap robocon yang cerdas tersebut. 


\subsection{Gungun}

Pengertian gungun adalah 'semakin' yang juga dapat dikualifikasikan secara perlahan-lahan mengalami perubahan. Hampir sama halnya dengan dondon, gungun juga merupakan kata keterangan yang biasanya digunakan untuk menunjukkan terjadinya perkembangan secara bertahap pada suatu hal (Daijisen, 1998:1094).

“物事が勢いよく進行するさま。どんどん。”

'Monogoto o ikioi yoku shinkousurusama. Dondon.'

'Sesuatu yang mengalami perubahan yang cepat. Semakin.'

Suatu perubahan yang terjadi secara natural atau alami dan merupakan hasil dari suatu situasi. Hanya saja sedikit berbeda dengan dondon yang tidak adanya keraguan pada perubahan yang terjadi. Fukushi gungun ini masih terdapat keraguan mengenai perubahan suatu hal namun perubahan yang terdapat pada gungun ini bersifat ke arah yang positif.

\subsubsection{Menerangkan kata kerja}

Berikut merupakan fungsi dandan yang digunakan untuk menjelaskan kata kerja.

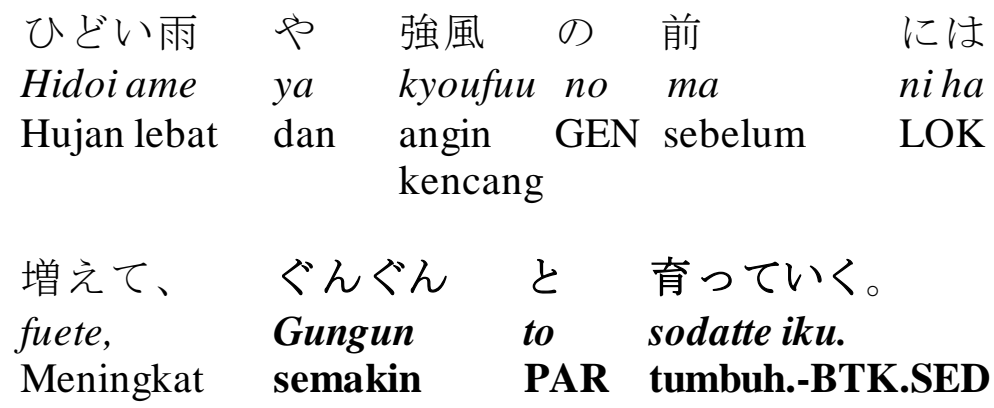

'Kristal meningkat sebelum hujan lebat dan angin kencang, kemudian semakin tumbuh (dengan mantap).'

Data (4) terdapat fukushi gungun yang diikuti oleh partikel to dan kata kerja. Gungun tersebut berfungsi untuk menerangkan sodateru yang merupakan kata kerja intransitif yang mengalami perubahan bentuk menjadi sodatte iku yang secara harfiah berarti 'tumbuh'. Kata tersebut diikuti oleh pola -te $i k u$ yang menunjukkan suatu kondisi yang berkelanjutan dengan bergerak menjauh dari pembicara (Arino, 1998:241). Sehingga jika gungun to sodatte iku jika diterjemahkan ke dalam bahasa Indonesia menjadi 'semakin tumbuh (dengan mantap)'. Pada kalimat tersebut, terdapat partikel to 
sebelum sodatte iku merupakan pilihan, tidak mewajibkan atau pun mengharuskan penggunaannya pada fungsi gungun. Kristal yang awalnya sudah bertambah akhimya menjadi semakin tumbuh dengan mantap dan menjadi lebih banyak sebelum terjadinya hujan lebat dan angin yang kencang.

\subsubsection{Menerangkan situasi dengan konteks tujuan}

Kalimat tersebut merupakan kalimat yang berisikan fukushi gungun yang menjelaskan konteks waktu. Situasi sebelumnya menjelaskan bahwa cairan transparan yang terperangkap dalam wadah berbahan dasar kaca menciptakan kristal yang sangat indah dan menawan. Hal tersebut disebabkan oleh adanya perubahan cuaca yang sangat singkat sehingga mengubah bentuk cairan transparan tersebut dan bercahaya terang pada posisinya. Namun sebelum hujan lebat dan angin kencang mengguncang tempat tersebut, cairan transparan yang berubah menjadi batu-batu kristal yang tumbuh semakin banyak. Gungun sodatte iku jika diterjemahkan ke dalam bahasa Indonesia berarti 'semakin tumbuh (lebih banyak)'. Perubahan tersebut terjadi dengan singkat secepat perubahan cuaca sesuai dengan konsep Akira. Makna kontekstual yang terdapat pada kalimat tersebut adalah konteks waktu karena menjelaskan proses pertumbuhan kristal-kristal. Adanya waktu yang dijelaskan secara tersirat pada perubahan cuaca ekstrim yang mengakibatkan pertumbuhan kristal semakin banyak.

\subsection{Masumasu}

Makino dan Tsutsui (A Dictionary of Advanced Japanese Grammar, 2008:148) menjelaskan bahwa fukushi masumasu yaitu: "Masumasu "more and more" is synonymous with ippou (da) when it means "continue to; keep ing". "masumasu adalah kata keterangan dalam bahasa Jepang yang dapat diartikan dengan "semakin" dan memiliki arti yang sama dengan iррои (da) apabila berarti "berlanjut; atau terusmenerus".

Buku Affective Expressions In Japanese menerangkan bahwa arti dari fukushi masumasu adalah 'semakin dan semakin' menurut Suleski dan Hiroko (2012:63). Kata keterangan ini menggambarkan sesuatu yang bertambah banyak maupun kuat secara jumlah. Masumasu jika diikuti dengan kata kerja positif, maka dapat diartikan sebagai penambahan jumlah dengan konotasi yang baik. Namun, apabila di belakang fukushi masumasu diikuti dengan kata kerja negatif maka kalimat tersebut dapat berarti negatif. 
Begitu pun dengan pengertian Akira yang terdapat pada buku Daijisen (1998) yang menyatakan perubahan pada masumasu dapat dikatakan lumayan ekstrim karena biasanya lebih besar kuantitasnya di banding dengan fukushi yang lain.

\subsubsection{Menerangkan Kata Sifat}

Berikut merupakan fungsi dandan yang digunakan untuk menjelaskan kata sifat.

\begin{tabular}{|c|c|c|c|c|}
\hline $\begin{array}{l}\text { Sono } \\
\text { Itu }\end{array}$ & $\begin{array}{l}\text { omoi } \\
\text { perasaan }\end{array}$ & $\begin{array}{l}h a \\
\text { TOP }\end{array}$ & $\begin{array}{l}\text { masumasu } \\
\text { semakin }\end{array}$ & $\begin{array}{l}\text { tsuyoi. } \\
\text { kuat. }\end{array}$ \\
\hline
\end{tabular}

Data (5) menunjukkan masumasu digunakan untuk menerangkan kata sifat, yaitu tsuyoi. Tsuyoi merupakan kata sifat i yang secara harfiah berarti 'kuat'. Masumasu tsuyoi jika diterjemahkan ke dalam bahasa Indonesia menjadi 'semakin kuat'. Kata tsuyoi tersebut bisa diterangkan dengan masumasu sehingga menjadi semakin atau lebih kuat dari sebelumnya. Oleh sebab itu, ditemukan fungsi masumasu yang dapat menerangkan kata sifat.

\subsubsection{Menjelaskan situasi dengan konteks}

Kalimat pada data (5) menjelaskan keadaan pemerintah yang merasa prihatin terhadap kehidupan para anti sosial yang selalu bermain judi. Situasi sebelumnya menjelaskan bahwa pemerintah mengumumkan akan menetapkan aturan kontak antara pelaku usaha, politisi dan pejabat pemerintah daerah, namun aturan dasar yang harus dimasukkan belum diperjelas. Editor dari salah satu koran terkenal di Jepang, yaitu Asahi Shinbun secara konsisten menentang larangan tetang kasino karena merasa khawatir dengan peningkatan kecanduan untuk berjudi yang menyebabkan hutang dan keruntuhan keluarga akan menjadi sumber penghasilan bagi pasukan anti sosial. Masumasu tsuyoi jika diterjemahkan ke dalam bahasa Indonesia menjadi 'semakin kuat'. Makna kontekstual yang terkandung pada data tersebut adalah konteks suasana hati pembicara karena pembicara memiliki perasaan yang semakin kuat untuk menentang larangan tersebut. 


\subsubsection{Menerangkan kata kerja}

Berikut merupakan fungsi dandan yang digunakan untuk menjelaskan kata kerja.

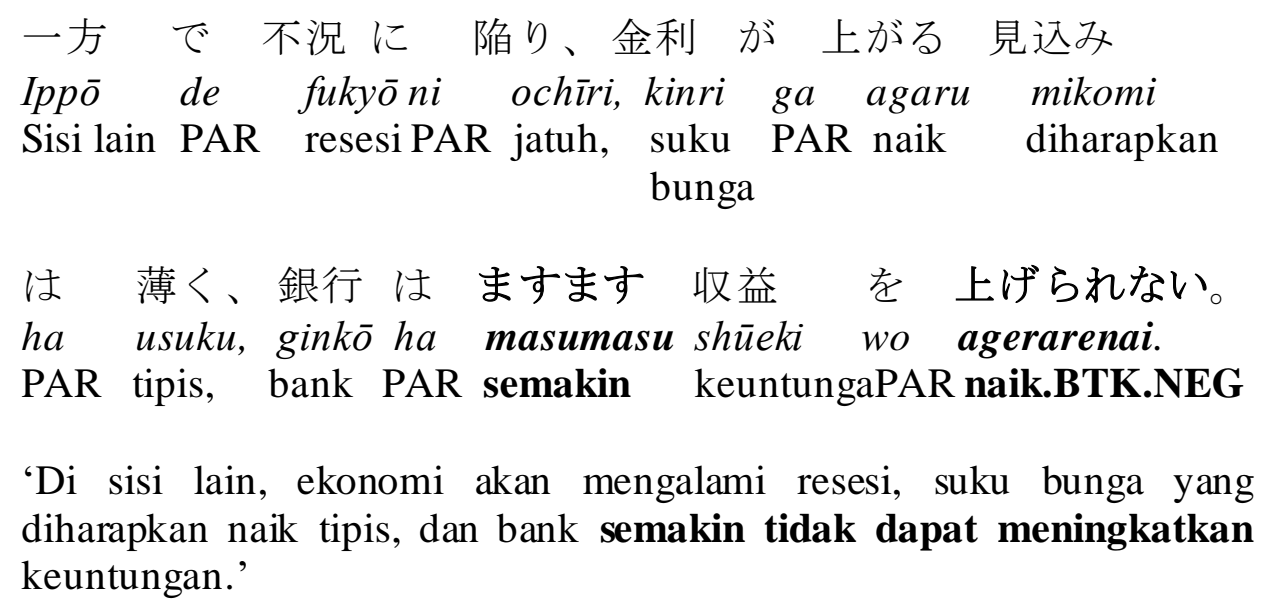

'Di sisi lain, ekonomi akan mengalami resesi, suku bunga yang diharapkan naik tipis, dan bank semakin tidak dapat meningkatkan keuntungan.'

Masumasu pada data (6) berfungsi untuk menerangkan kata kerja transitif bentuk potensial negatif atau -rarenai. Ageru merupakan kata kerja bentuk kamus, bila diubah menjadi bentuk potensial menjadi agerareru yang secara harfiah berarti 'dapat naik'. Agerarenai berasal dari kata agerareru yang mengalami perubahan ke dalam bentuk negatif -nai menjadi agerarenai. Pada kalimat tersebut, masumasu agerarenai jika diterjemahkan ke dalam bahasa Indonesia menjadi 'semakin tidak dapat meningkatkan'. Maksud dari pengertian 'semakin tidak dapat meningkatkan' adalah keuntungan uang yang didapat oleh bank akan sulit untuk mencapai peningkatan. Perubahan yang dialami terjadi dengan skala yang besar dan meluas.

\subsubsection{Menjelaskan kondisi dengan konteks situasi}

Makna kontekstual yang terdapat pada data (6) adalah konteks situasi karena menjelaskan situasi kondisi perekonomian masyarakat. Pada kalimat sebelumnya, seseorang yang bernama Wolfgang Kurt mengatakan bahwa beliau sangat senang dengan penggunaan sistem pembayaran non-tunai. Beliau juga menyatakan bahwa dari sistem itu juga dapat menguntungkan bank karena mendapatkan nasabah lebih banyak. Namun, jika dilihat dari sisi lain, perekonomian akan mengalami penurunan kegiatan dagang atau industri dan bank semakin tidak dapat meningkatkan keuntungan yang diraih. Masumasu agerarenai jika diterjemahkan ke dalam Bahasa Indonesia, yaitu 'semakin tidak dapat meningkat'. Konteks objek yang dimaksud pada kalimat tersebut adalah kondisi perekonomian masyarakat dan bank yang mengalami perubahan dengan 
jumlah yang besar karena membahas ekonomi suatu wilayah sesuai dengan konsep yang diutarakan oleh Akira.

\section{Simpulan}

Berdasarkan hasil analisis dapat disimpulkan bahwa fukushi dandan, dondon, gungun, dan masumasu dapat difungsikan untuk menerangkan kata kerja, baik itu kata kerja transitif maupun kata kerja intransitif. Fukushi dandan dan dondon selain berfungsi untuk menerangkan kata kerja, dapat pula digunakan untuk menerangkan kata benda. Selain itu, ditemukan juga data yang menerangkan frasa kerja pada dandan. Pada data fukushi dandan, ditemukan banyak kata kerja bentuk -te kuru yang menjelaskan kondisi sutau hal yang mengalami perubahan dengan mendekati pembicara. Fukushi dondon yang ditemukan pada data banyak diikuti oleh kata kerja dengan pola -te iku yang memiliki arti suatu perubahan kondisi yang mengalami perubahan dengan menjauhi pembicara. Selain itu, fukushi gungun hanya bisa diikuti oleh kata kerja. Demikian pula dengan fukushi masumasu, selain bisa digunakan untuk menerangkan kata kerja, masumasu juga dapat difungsikan untuk menerangkan kata sifat. Fukushi masumasu juga banyak diikuti oleh kata kerja dengan pola -te iku yang bermaksud bahwa perubahan yang menjauhi pembicara. Keempat fukushi tersebut memiliki arti yang sama, yaitu 'semakin'.

Fukushi dandan dapat diikuti oleh kata kerja dan kata benda berdasakan konsep yang dikemukakan oleh Akira. Berdasarkan hasil yang ditemukan terdapat beberapa data yang menerangkan kata kerja, kata benda dan frasa kerja. Dandan memiliki arti 'semakin' yang mengalami perubahan secara perlahan dan relatif lebih lama dibanding dengan dondon. Dandan memiliki makna kontekstual sebanyak 4 jenis yaitu, 1) konteks waktu, 2) konteks suasana hati pembicara atau pendengar, 3) konteks situasi, dan 4) konteks tujuan. Fukushi dondon berfungsi untuk menerangkan kata kerja dan kata benda. Kata kerja yang mengikuti dondon terdapat dua jenis, yaitu kata kerja transitif dan kata kerja intransitif. Arti dondon adalah 'semakin', namun memiliki proses perubahan yang relatif lebih cepat dan tanpa keraguan. Makna kontekstual yang terdapat pada dondon ada 3 jenis yaitu, 1) konteks tujuan, 2) konteks situasi dan 3) konteks objek. Fukushi gungun juga memiliki arti yang sama dengan 2 fukushi sebelumnya, yaitu 'semakin', namun proses perubahan yang terjadi secara cepat atau singkat dan dilakukan dengan kekuatan penuh. Gungun hanya digunakan untuk menerangkan kata kerja dan ditemukan 4 data. Fukushi ini sangat jarang digunakan, sehingga paling sedikit data yang dapat ditemukan pada artikel. Makna kontekstual yang terdapat pada gungun adalah 1) konteks suasana hati pembicara atau pendengar dan 2) konteks tujuan. Masumasu dapat diikuti oleh kata kerja dan kata sifat. Masumasu yang menerangkan kata kerja ditemukan beberapa data dan terdapat satu data yang menerangkan kata sifat. Masumasu juga memiliki arti 'semakin', namun perbedaannya ada pada perubahan yang terjadi memiliki skala yang besar atau ekstrim. Masumasu memiliki makna kontekstual sebanyak 4 jenis yaitu, 1) konteks waktu, 2) konteks situasi, 3) konteks suasana hati pembicara atau pendengar dan 4) konteks objek. 


\section{Daftar Pustaka}

Akira, Matsumura. 1998. Daijisen. Tokyo: Shougakukan.

Arino, Sagawa. 1998. Nihongo Bunkei Ziten. Tokyo: Kuroshio Shuppan.

Makino, Seiichi dan Michio Tsutsui, 2008. A Dictionary of Advanced Japanese Grammar. Tokyo: The Japan Times.

Sudaryanto. 1993. Metode dan Aneka Teknik Analisis Bahasa (Pengantar Penelitian Wahana Kebudayaan Secara Linguistik). Yogyakarta: Duta Wahana University Press.

Suleski, Ronald dan Masada Hiroko. 2012. Affective Expressions in Japanese. Tangerang Selatan: Alkitabah.

Verhaar, J.W.M. 2010. Asas-Asas Linguistik Umum. Yogyakarta : Gadjah Mada University Press. 